\title{
イオンマイクロアナライザによる低合金鋼の 定量分析
}

\section{Quantitatiue Analysis of Low Alloy Steel with an Ion Microanalyzer}

\author{
近 藤 敏 郎*·田村一二三*·石 谷 亨* · 中 村一 光** \\ Toshio Kondo, Hifumi Tamura, Tohru Ishitani and Kazumitu NaKamura
}

(1975年10月20日受理)

\begin{abstract}
A thermodynamic approach to quantitative analysis with an ion microanalyzer(IMA) was applied to standard samples of low alloy steel for the two different measurements. The one of them was at an oxygen partial pressure of $5 \times 10^{-5}$ Torr in the sample chamber of IMA and the other was at high vacumm of $\sim 10^{-7}$ Torr. The error of the quantitative analysis was discussed. The results by the IMA quantitative analysis were referred to the wet chemical analysis. The error in the IMA analysis for two measurements is almost same, and to a certain extent is observed.
\end{abstract}

\section{1. 緒言}

イオンマイクロアナライザ (IMA) は固体表面の微 小部およびバルクの微量分析を行なう上で有用な分析 機器として注目されている。その定量分析法として, 標準試料が存在する場合検量線法が有用なことが報告 されているが, ${ }^{1)}$ 標準試料が得られない試料の分析に は適用できない。最近，IMAにおける定量分析法とし て, 試料面上の一次イオン照射部に局所的熱平衝プラ ズマが生成されていると仮定して, 試料のスパッ夕粒 子のイオン化率を考虑して定量補正する熱力学的解析 による方法が提案されている。 法のように分析対象の元素について標準試料を必要と しないのが特長である。

本報告は熱力学的解析による定量分析法を評価する ため行なった実験について記述したものである。低合 金鋼の試料に酸素イオンの一次イオンビームを照射し た場合の実験結果について検討した。この実験におい て，IMAの試料室を高真空にして測定を行なう通常の 方法と試料室に酸素ガスを導入して感度を高くする方
法をとりあげた。このような異なった測定条件で得ら れた定量分析結果についても報告する。

\section{2. 定量分析の原理}

IMAにおいて試料表面に一次イオンビームが照射さ れたとき，その部分に局所的熱平衝プラズマが形成さ れているものと考える。この局所的熱平衝プラズマ中 において，Mなる元素について考えるとスパッタによ り放出された原子の総数 $n_{\mathrm{M}}$ 個は $n^{+}, n^{-}, n_{0}, n_{\mathrm{M} 0}$, $n_{\mathrm{MO}_{2}}$ 個の正イオン, 負イオン, 中性原子, monoxide 分子, および dioxide 分子などを含んでいるものと 考えられる。すなわち

$$
n_{\mathrm{M}}=n^{+}+n^{-}+n_{\mathrm{o}}+n_{\mathrm{Mo}}+n_{\mathrm{M} \mathrm{o}_{2}} .
$$

本報告では，次式に示すように大部分の原子Mo は 1 価の正イオン $\mathrm{M}^{+}$と電子 $\mathrm{e}^{-}$に解離するものと考え, 多価イオン, 負イオン, monoxide イオンについては, その量が少ないものとしてとりあげないこととする。

$$
\mathrm{M}_{\mathrm{o}} \rightleftharpoons \mathrm{M}^{+}+\mathrm{e}
$$

* 日立製作所中央研究所（東京都国分寺市 280)

Central Research Lab., Hitachi, Ltd. (280 Koubunji, Tokyo)

**日立製作所那珂工場（茨城県勝田市市毛 882）

Naka works, Hitachi, Ltd. (882 Ichige, Katsuta, Ibaraki) 
近藤・田村 · 石谷 $\cdot$ 中村

この反応において, dissociation constant $\mathrm{K}_{\mathrm{n}}{ }^{+}$は次 式で与えられる。

$$
K_{\mathrm{n}}^{+}=\frac{n^{+} n_{\mathrm{e}}}{n_{\mathrm{o}}}
$$

ここに $n^{+}, n_{\mathrm{e}}, n_{\mathrm{o}}$ はそれぞれ単位体䅡あたりの 1 価 イオン, 電子, 中性原子の数である。

熱平衝条件において，プラズマ中の各元素の原子と イオンの比率は次のSaha-Eggertの式で表わせる。

$$
K_{\mathrm{n}}=\left(\frac{2 \pi}{h^{2}} \cdot \frac{n^{+} n_{\mathrm{e}}}{n_{\mathrm{o}}} k T\right)^{3 / 2} \frac{U^{+} U_{\mathrm{e}}}{U_{\mathrm{o}}} e^{-E / k T} \quad(2 \cdot 4)
$$

ここにhはPlankの定数， $k$ はBoltzman定数，Tは 絶対温度, $m$ は質量数, $U^{+}, U_{\mathrm{e}}, U_{\mathrm{o}}$ はそれぞれ正 イ オン, 電子, 原子の分配関数, $E$ は解離エネルギーで 原子の第一イオン化電圧である。上記の式 $(2 \cdot 3)$ と式 $(2 \cdot 4)$ より常用対数を用いた実用的な式で表 わすと次のようになる。

$$
\begin{aligned}
\log \frac{n^{+}}{n_{\mathrm{o}}}= & 15.38+\log \frac{2 U^{+}}{U_{\mathrm{o}}}+1.5 \log T \\
& -\frac{5040}{T}(E-\Delta E)-\log n_{\mathrm{e}}(2 \cdot 5)
\end{aligned}
$$

ここに $U_{\mathrm{e}}=2$ とした。 $\Delta E$ は電子温度 $T$ と電子密 度 neよってきまる potential depressionの項で次式 で与えられる。

$$
\begin{gathered}
\Delta E=2.95 \times 10^{-8} \times \gamma \times\left(\frac{n_{\mathrm{e}}}{T}\right)^{1 / 2}, \\
\gamma=1.20 \pm 0.24
\end{gathered}
$$

原子およびイオンの分配関数 $U_{\mathrm{o}}, U^{+}$はH. W. Drawin によって計算された表 ${ }^{4)}$ あるいはL. D. Galanによっ て与えられた表 ${ }^{5)}$ から求めることができる。 H.W. Drawinの表は広範囲の $T$ に対する $U_{0}$ と $U^{+}$の值が与え られているのが特微である。また $\Delta E$ の大きさによる 補正值も与えられている。このように正確な数值が与 えられているのは利点であるが, 実用上所望の数值を 得るための手続が面倒である。

一方, L. D. Galanの方法は次式に示すようにプラズ マの電子温度 $T$ の関数として分配関数 $B(T)$ を与えて いる。

$$
\begin{aligned}
B(T)= & \mathrm{a}+\mathrm{b}\left(\frac{T}{10^{3}}\right)+C\left(\frac{T}{10^{3}}\right)^{2}+d\left(\frac{T}{10^{3}}\right)^{3} \\
& +e\left(\frac{T}{10^{3}}\right)^{4}+f\left(\frac{T}{10^{3}}\right)^{5}
\end{aligned}
$$

ここにTの 5 次の多項式として表わした $B(T)$ にお いて, 係数 $a, b . c, d, e, f$ は73種の元素の原子 および1価イオンについて与えられている。このよう
に各元素について， $a, b, c, d, e, f$ 数值を与える だけで広範囲の $T$ に対応した分配関数が簡単に求めら れる。この分配関数が適用できる温度篹囲は $1500^{\circ} \sim$ $7000^{\circ} \mathrm{K}$ である。分配関数を $T$ の 5 次式で近似すること

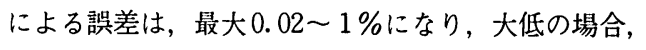
誤差は $0.01 \%$ 以内といわれている。本報告では, 定年 分析の計算過程で与えられるプラズマ中の電子温度が とりうる範囲にあることのほか, 数值計算の容易なこ とおよび計算機に必要とする記憶容量などの実用面も 考虑してGalanによる方法で分配関数を求めることに した。

式 $(2 \cdot 5)$ はプラズマ中の電子温度 $T$ と電子密度 $n_{\mathrm{e}}$ が定まると中性原子の数 $n_{\mathrm{o}}$ と 1 価イオンの数 $n^{+}$の比 $\left(n^{+} / n_{\mathrm{o}}\right)$ が与えられることを示している。したがっ てTと $n_{\mathrm{e}}$ 与えると $\left(n^{+} / n_{\mathrm{o}}\right)$ 求めることができる。

IMAにおける試料面上の局所的熱平衝プラズマ中の 1 価イオンの数 $n^{+}$と検知されるイオン電流 $I$ は, イオ ン検知器の効率がイオンの質量数 $M$ の平方根の逆数に 比例すると仮定して次のように関係づけることができ る。

$$
n^{+}=k \sqrt{M} I
$$

ここに $k$ は, 二次イオン加速電圧, 二次イオンのと り出し角など装置によって決まる比例定数である。

一方, 試料面上でスパッタされる元素 $M$ の原子数 $n_{\mathrm{M}}$ とイオン数 $n_{M}{ }^{+}$は次式で与えられる。これょり元素 $M$ のイオン数は $n^{+}$添字 $M$ をつけることにする。

$$
\frac{n_{M}^{+}}{n_{\mathrm{M}}}=\frac{n_{\mathrm{M}}^{+}}{n_{\mathrm{M}}^{\mathrm{o}}+n_{\mathrm{M}}^{+}}=\frac{\frac{n_{\mathrm{M}}^{+}}{n_{\mathrm{M}}^{\circ}}}{1+\frac{n_{\mathrm{M}}^{+}}{n_{\mathrm{M}}^{\circ}}}
$$

したがってスパッタされた原子数 $n_{\mathrm{M}}$ は

$$
n_{\mathrm{M}}=n_{\mathrm{M}}^{+}\left[\frac{\frac{n_{\mathrm{M}}^{+}}{n_{\mathrm{M}}^{\circ}}}{1+\frac{n_{\mathrm{M}}^{+}}{n_{\mathrm{M}}^{\circ}}}\right]^{-1}=k \sqrt{ } M I_{\mathrm{M}}\left(\frac{\frac{n_{\mathrm{M}}^{+}}{n_{\mathrm{M}}^{\mathrm{M}}}}{1+\left(\frac{n_{\mathrm{M}}^{+}}{n_{\mathrm{M}}^{\mathrm{o}}}\right.}\right)^{-1}(2
$$

となる。この式を用い元素 $M$ の原子濃度 $C_{M}$ は次式から 求めることができる。

$$
C_{\mathrm{M}}=\frac{n_{\mathrm{M}}}{\sum_{\mathrm{M}}\left(n_{\mathrm{M}}^{+}+n_{\mathrm{M}}^{\circ}\right)}
$$

以上の式より, 元素濃度を知るため $T$ と $n_{\mathrm{e}}$ を求めな ければならない。これらの数值を決定するためには， 2 種以上の元素について濃度が既知の試料を式（2．

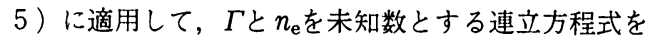


解けばよい。以下本報告では，試料中に濃度が既知の 元素 (内部標準) が少なくとも2 種存在する場合の熱 力学的解析による定量分析法について検討する。

\section{3. 定量分析値の計算方法}

前章で述べた原理の定量分析を数值計算により実施 した。この計算を実施するためのプログラムは次の部 分からできている。

（1）プラズマの電子温度と密度の初期値，および計 算による分析値の許容誤差など数值の読み込み。

(2) 元素毎の分配関数のデータおよび原子質量の読 み込み。

(3) 試料のデータ（内部標隼元素名と濃度, 未知元 素名とIMAの測定ピーク值) の読み込み。

（4）必要なデー夕を（2）で読み込んだデータより 探索する。

(5) 分配関数の計算。

（6）プラズマの電子温度 $T$ と密度 $n_{\mathrm{e}}$ の最適值の決定 (すでに与えられている内部標準元素の既知原子 濃度 $C^{\prime}{ }_{M}$ に計算により求めようとする内部標準元 素の原子濃度 $C_{\mathrm{M}}$ が一定誤差内で一致するような $T$ と $n_{\mathrm{e}}$ の值を求める)

(7) 求めた $T$ と $n_{\mathrm{e}}$ 值より未知元素の濃度を計算する。 (8) 定量分析結果の印字

定量分析値を算出する過程のフローチャートをFig. 1 に示す。

\section{4. 実験方法と結果}

\section{1 装置および実験方法}

前章で述べた定量分析法を低合金鋼に適用した場合 について検討するための実験を行なった。実験には日 立IMA-2 型イオンマイクロアナライザ ${ }^{6)}$ を用いた。 ここに用いたIMAはFig. 2 にその全体構成図を示すよ うに，一次イオン照射系，二重収束形質量分析計，お よび走査形イオン顕微鏡から構成されている。一次イ オン照射系は一次イオンを発生させるためのイオン銃, 目的に応じて試料表面に照射されたイオンビームの径 および強度を調整するための 2 段の静電レンズ系とイ オンビームを試料面上で走査させるための偏向電極か ら構成されている。イオン銃はカソード, 中間電極, アノード，制御電極および引出し電極から構成されて いる。イオン銃において，従来酸化物カソードが用い られていたが, 今回は一次イオンとして酸素イオンを

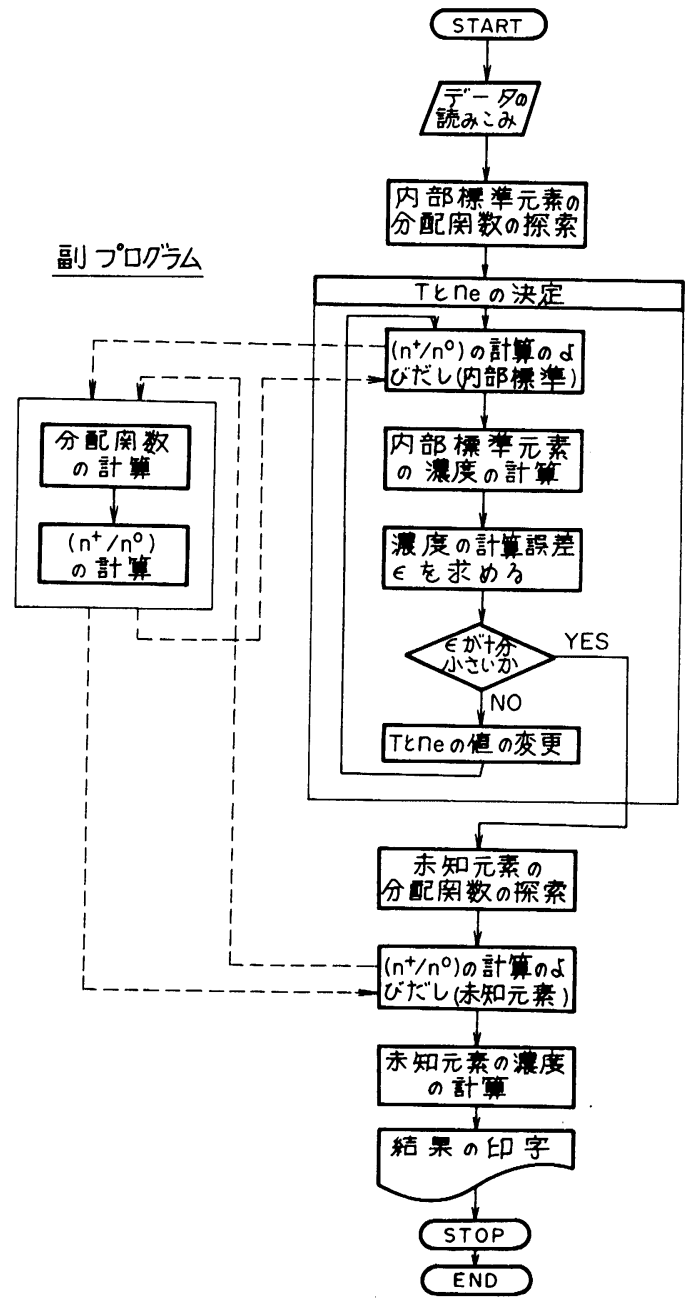

Fig. 1. Flow chart of the quantitative analysis program. 用いるため上記のカソードを活性ガスイオンにも利用 できるホローカソードに改良した。7)

質量分析計には，二次イオン引出し電極とイオンの 軌道を補正するための静電レンズを備えた二重収束型 質量分析計が用いられている。ここでの $\beta$ スリットは 単に特定エネルギーの二次イオンのみを通過させる役 割と共にスリットの周辺に流入するイオン電流を測定 することにより二次イオンの変動を検知することがで きる。二次イオンはベリリウム銅合金のダイノード16 段で構成された二次電子増倍管とエレクトロメーター で検知するようになっている。

IMAの試料室はイオン銃にガスを流入して動作させ た時においても〜10-7 Torrの高真空に保つことができ る。試料室をこのような高真空にした場合と, 感度を 


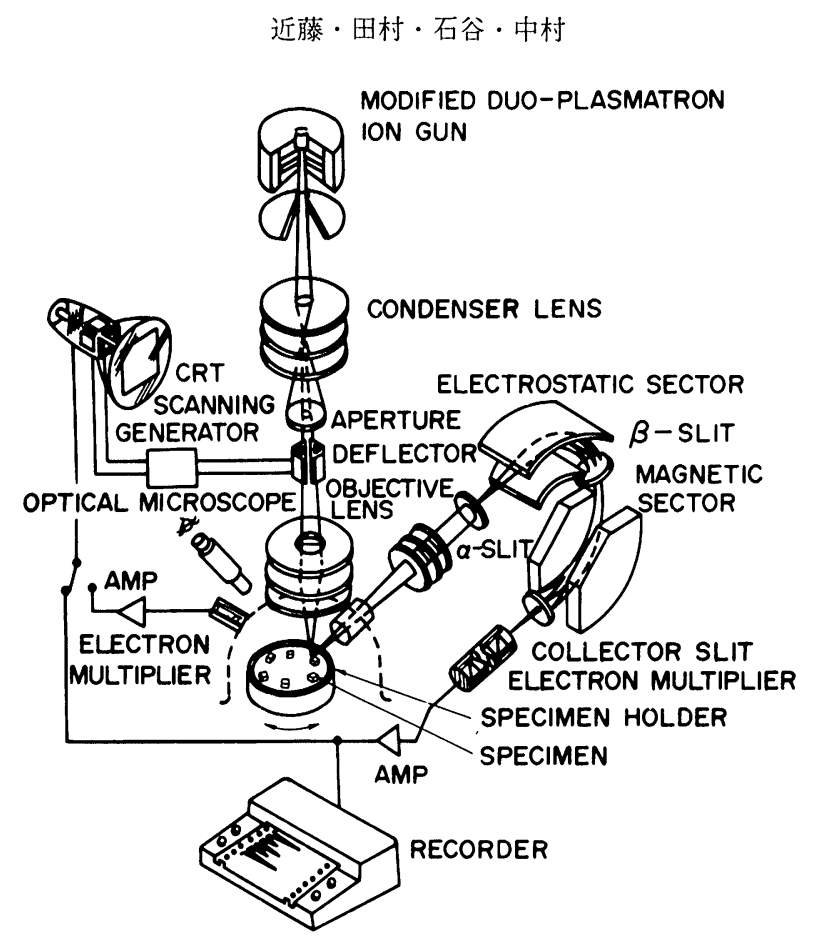

Fig. 2. Schematic diagram of the ion microanalyzer used in the experiment.

向上させるため試料室に酸素ガスを導入した場合に ついて検討した。試料室への酸素ガスの導入はニード ルバルブを用いて行ない, 測定時の試料室のガス圧は 二次イオン生成些が最大となる $5 \times 10^{-5}$ Torr とした。 化学分析によりその組成と濃度が明らかな低合金鋼 (Analyzed Sample Ltd製造) を試料として用い, $7 \mathrm{KeV}$ のエネルギーで一次イオンを照射した。一次イ オンを試料に照射した初期において, 表面状態により 二次イオンの生成㱔が変動する。この影響をさけるた め, $\beta$ スリットに流入する二次イオン電流をモニタし て, この変動が十分小さくなった時点で測定を行なう ようにした。また試料に偏折があれば測定誤差が生じ るため, 試料面数ケ所で同様の測定を行ない, 得られ た結果に大きな差異が見られないことを確認した。

\section{2 測定結果}

IMAで測定された低合金鋼の質量スペクトルから含 まれている各元素のイオン強度を求めるに際し，互に 他の元素の同位体のピークと重畳しない質昌数のピー クを選んだ。ピーク高を読みとるためとりあげた各元 素の同位体は次の通りである。

${ }^{56} \mathrm{Fe},{ }^{55} \mathrm{Mn},{ }^{60} \mathrm{Ni},{ }^{52} \mathrm{Cr},{ }^{98} \mathrm{Mo},{ }^{56} \mathrm{~V},{ }^{63} \mathrm{Cu}$

IMAで測定した上記の同位体のピークの高さから， それぞれの元素においてすべての同位体を含めたイオ ン強度を求めた。すなわち同位体補正を行なった。こ
の算出に際し, 各元素の同位体天然存在率は, Nuclear Data Tables（1959）においてNierにより最適値とさ れている値 ${ }^{8)}$ を引用した。

以上の手順で質照スペクトルから求めた各元䋈のイ オン強度とすでに与えられている化学分析值より検正 線を作成した。IMAの試料室を高真空 $\left(\sim 10^{-7} \mathrm{Torr}\right)$ にした場合の測定結果から求めた検垶線を Fig. 3に, 試料室に酸素ガスを導入した場合 $\left(5 \times 10^{-5} \mathrm{Torr}\right)$ の 測定結果から求めた検量線を Fig. 4 に示す。図中に示 した数字は, 試料番号を示し, 例えば $3,5,8$ はそ れぞれ SS3/1，SS5/1，SS8/1 試料の值を示し ている。

\section{3 定量分析結果}

試料としてとりあげた低合金鋼中の元素は化学分析 により濃度が既知である。したがってこれらの元素よ り適宜 2 種類の元素を内部標準とし, 他の元索を濃度 が未知の元素としてその濃度を求めることができる。 このようにして求めた各元素の濃度をすでに化学分析 により知られている濃度と比較することにより本稿で とりあげた定量分析法の評価を行なった。ここでは内 部標準として, 鉄を中心に鉄とシリコン, 鉄とマンガ ン, 鉄とニッケル, 鉄とクロム, 鉄とモリブデン, 鉄 とバナジンおよび鉄と銅などの組合せをとりあげた。 このように内部標準の異なった場合のIMAによる定显 


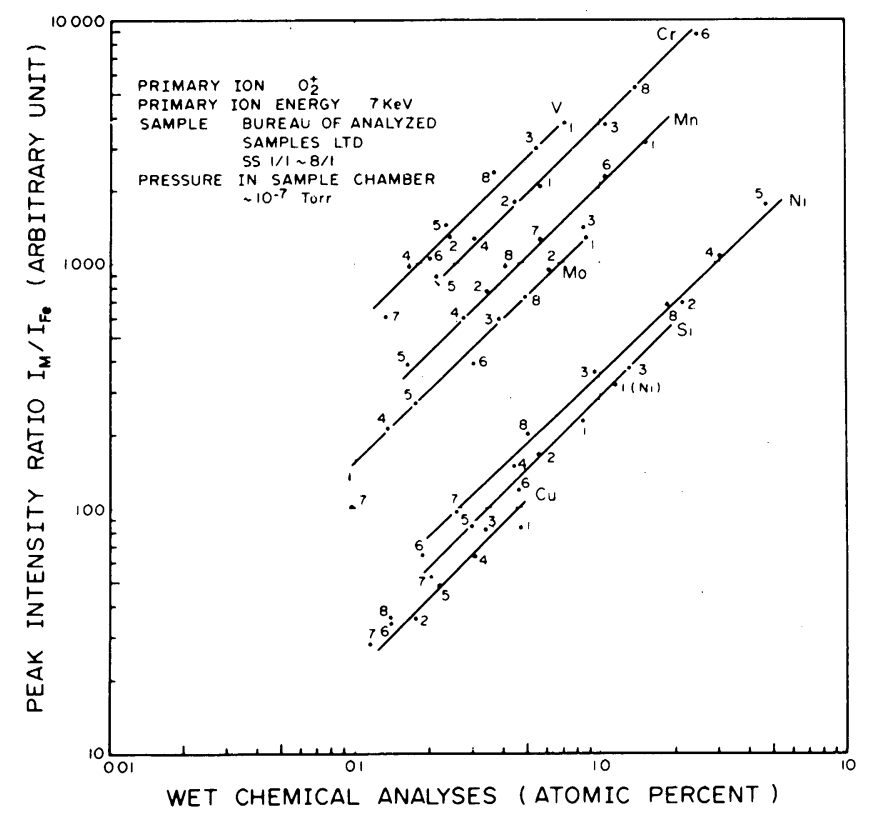

Fig. 3. Calibration curves for $\mathrm{Si}, \mathrm{Mn}, \mathrm{Ni}, \mathrm{Cr}, \mathrm{Mo}, \mathrm{V}$, and $\mathrm{Cu}$ in low alloy steel samples. Sample number expresses in figures.

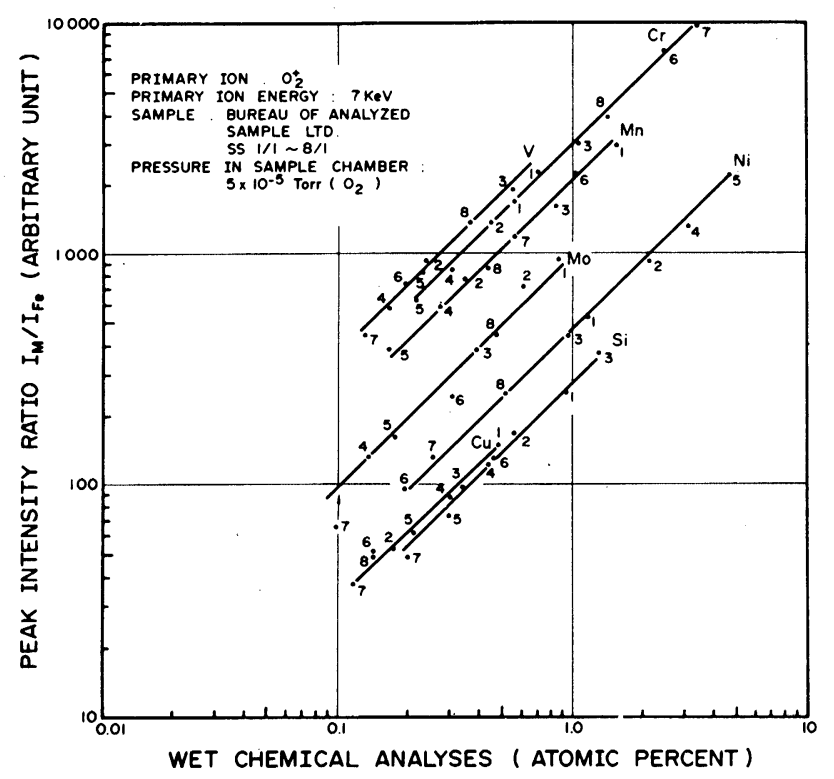

Fig. 4. Calibration curves for $\mathrm{Si}, \mathrm{Mn}, \mathrm{Ni}, \mathrm{Cr}, \mathrm{Mo}, \mathrm{V}$, and $\mathrm{Cu}$ in low alloy steel samples. Sample number expresses in figures.

分析値と化学分析値を比較した。これらの代表例を

Fig. $5 \sim$ Fig. 10 に示す。Fig. 5〜Fig. 7 は, IMAの 試料室を高真空にして測定した結果より求めたIMAに
よる分析值と化学分析値の関係を示したものである。 Fig. 8〜 Fig. 10はIMAの試料室に酸素がスに導入し て測定した結果より求めたIMA分析值と化学分析值の 


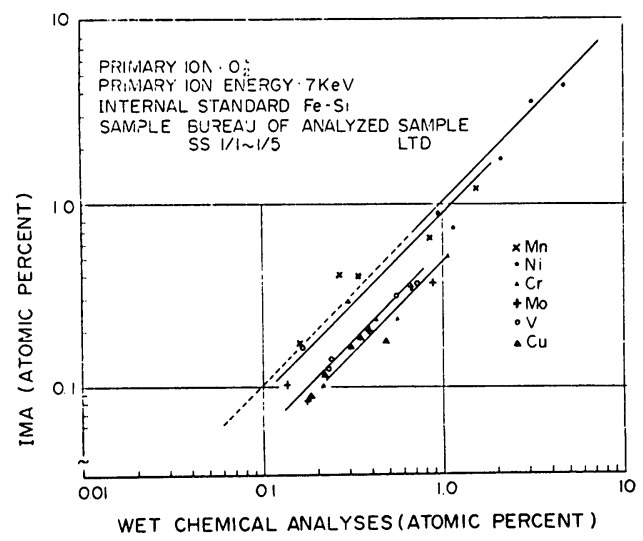

Fig. 5. Comparison of the analyses with the ion microanalyzer (IMA) and with chemical analyses for a number of elements in low alloy steel samples. Internal standards are $\mathrm{Fe}$ and $\mathrm{Si}$.

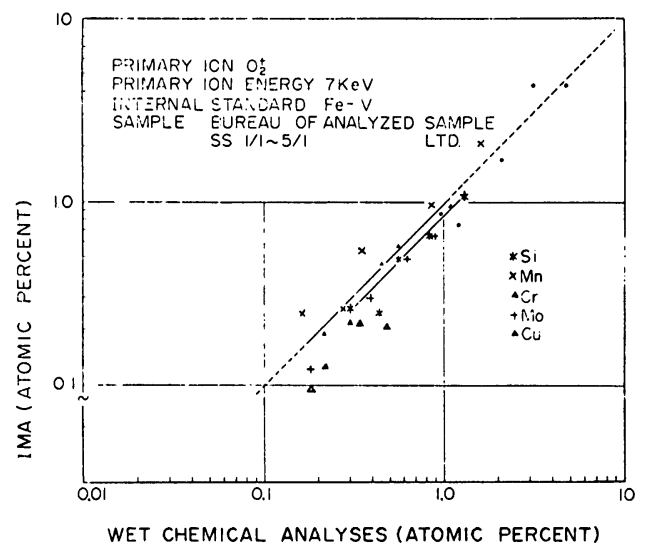

Fig. 6. Comparison of the analyses with the ion microanalyzer (IMA) and with chemical analyses for a number of elements in low alloy steel samples. Internal standards are $\mathrm{Fe}$ and $\mathrm{V}$.

関係を示したものである。ここに示された分析例にお いて, 鉄とシリコン元素を内部標準とした場合はいづ れもクロム, バナジン, 銅のIMA分析值が化学分析值 に対し大きい偏りを示している。このような特定の分 析例をのぞくと, 大部分の分析例において IMA分析值 は化学分析值と比較的良く一致している。

\section{5. 考察}

さきに示した分析例において，その分析誤差は内部 標準の選び方によって異なっている。また分析対象の

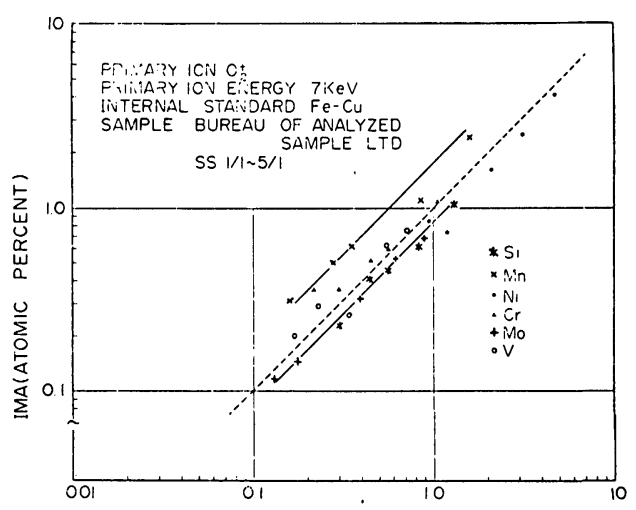

WET CHEMICAL ANALYSES (ATOMIC PERCENT)

Fig. 7. Comparison of the analyses with the ion microanalyzer (IMA) and with chemical analyses for a number of elements in low alloy steel samples. Internal standards are $\mathrm{Fe}$ and $\mathrm{Cu}$.

元素によっても分析誤差が異なるが，その大きさは元 素固有の系統的な偏りが認められるのみである。すな わちIMA分析値は化学分析値に比例しており, 分析請 差は濃度に関係していない。ここで内部標準が異なっ た場合も含め全元素についての平均分析誤差を含める ことにした。試料としてとりあげた低合金鋼に含まれ ている全元素を内部標準とした場合の平均分析誤差を 計算した。その計算方法について述べる。

定量分析の計算過程で必要とする局所的熱平衝プラ ズマの電子温度と電子密度は試料として用いた低合金 鋼に含まれている 8 種類の元素すべてを内部標準とし て決定し，各元素の濃度を算出する。これら各元素の 濃度はすでに与えられている化学分析值と比較するこ とにより分析誤差を求める。このようにして求めたそ れぞれ元素毎の分析誤差の平均值をとりあげた試料に ついての平均分析誤差とした。

実験に用いた 5 種類の試料 (Analyzed Sample Ltd. 低合合鋼 SS1 / 1 SS5/1) についての平均分析誤差 をTable 1 と Table 2 に示す。計算過程で求めたプ ラズマの電子温度と電子密度を併わせて示す。IMAの 試料室を高真空にして測定した場合と酸素ガスを導入 して酸素ガスの圧力を高くした場合の結果を表に示し たが，いづれにおいても平均24〜27\%の大差のない訹 差で分析できることがわかる。またIMAの試料室の酸 素ガスの圧力が高くなるとプラズマの電子温度が平均 $190^{\circ} \mathrm{K}$ 上昇していることが認められる。 


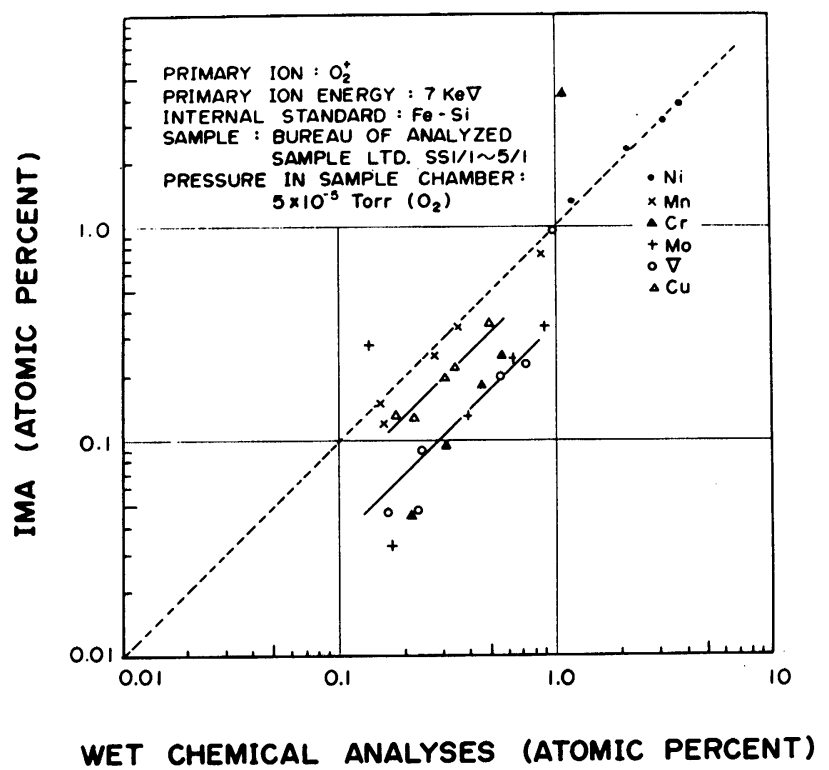

Fig. 8 Comparison of the analyses with the ion microanalyzer (IMA) and with chemical analyses for a number of elements in low alloy steel samples. Internal standards are $\mathrm{Fe}$ and $\mathrm{Si}$.

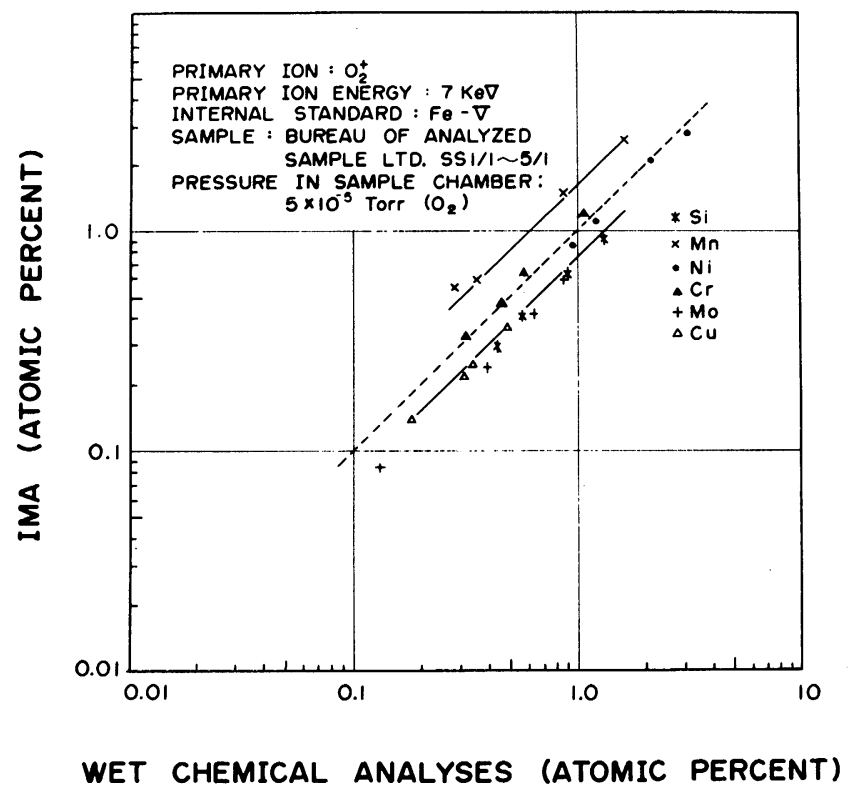

Fig. 9. Comparison of the analyses with the ion microanalyzer (IMA) and with chemical analyses for a number of elements in low alloy steel samples. Internal standards are $\mathrm{Fe}$ and $\mathrm{V}$. 


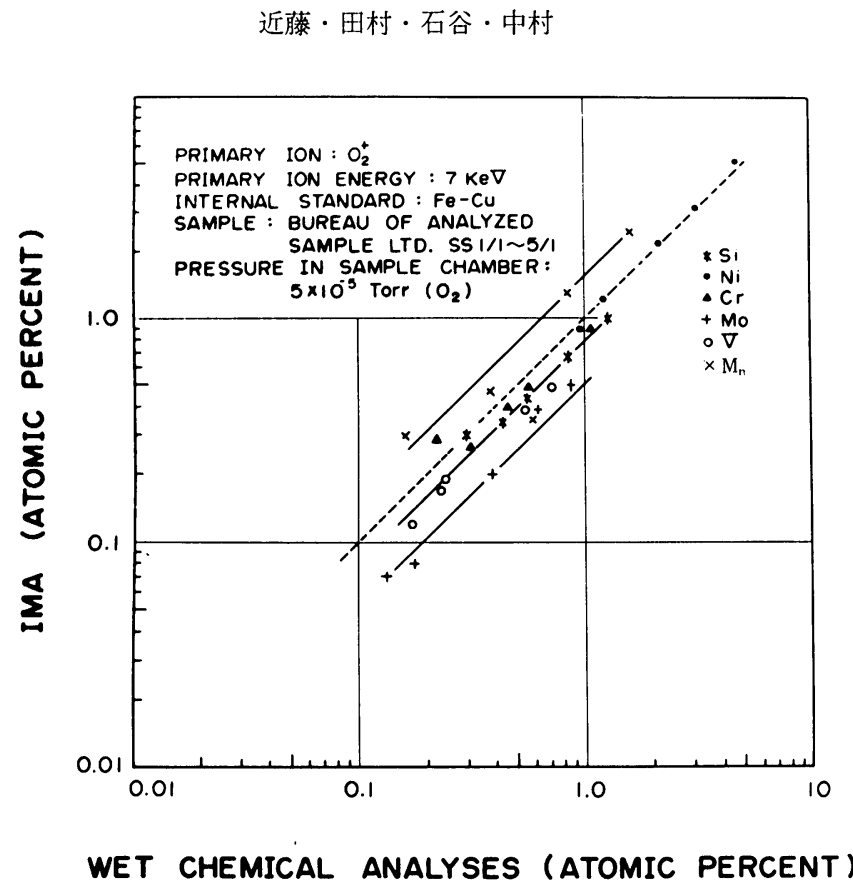

Fig. 10 Comparison of the analyses with the ion microanalyzer (IMA) and with chemical analyses for a number of elements in low alloy steel samples. Internal stands are $\mathrm{Fe}$ and $\mathrm{Cu}$.

Table 1. Mean errors of quantitative analysis with IMA for low alloy steel samples. Estimated values of electron temperature and electron density for these samples are also given in this table.

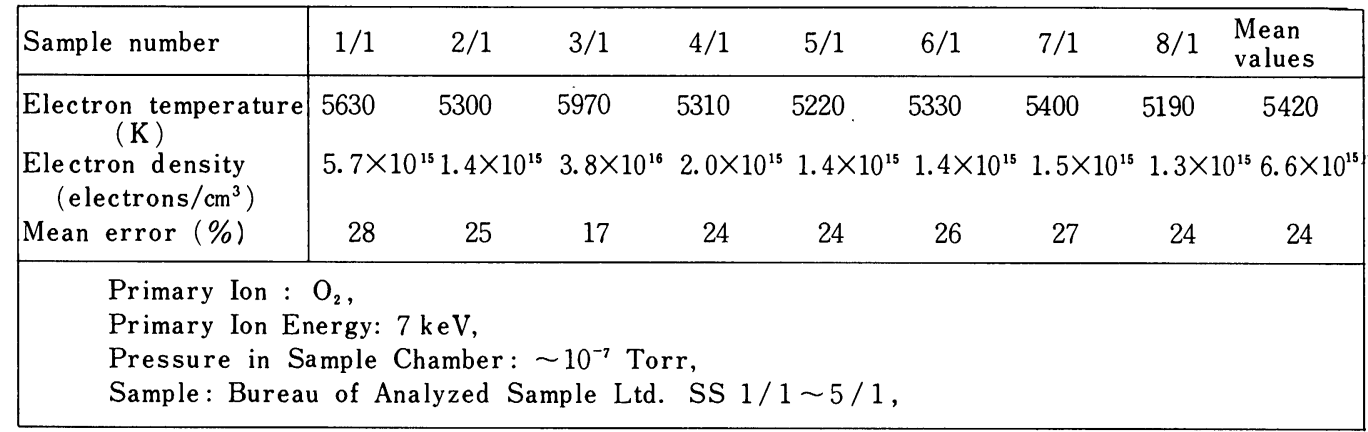


Table 2. Mean errors of quautitative analysis with IMA for low alloy steel samples. Estimated values of electron temperature and electron density of these samples are also given in this table.

\begin{tabular}{|c|c|c|c|c|c|c|c|c|c|}
\hline Sample number & $1 / 1$ & $2 / 1$ & $3 / 1$ & $4 / 1$ & $5 / 1$ & $6 / 1$ & $7 / 1$ & $8 / 1$ & $\begin{array}{l}\text { Mean } \\
\text { values }\end{array}$ \\
\hline \multirow{3}{*}{$\begin{array}{l}\text { Electron temperatur } \\
\quad(\mathrm{K}) \\
\text { Electron density } \\
\quad\left(\text { electrons } / \mathrm{cm}^{3}\right) \\
\text { Mean error }(\%)\end{array}$} & 5830 & 5540 & 5810 & 5600 & 5500 & 5580 & 5610 & 5580 & 5630 \\
\hline & $2.9 \times 10^{15}$ & ${ }^{5} 1.3 \times 10^{15}$ & ${ }^{5} 2.7 \times 10^{15}$ & $1.3 \times 10^{15}$ & ${ }^{5} 1.0 \times 10^{15}$ & $1.5 \times 10^{15}$ & ${ }^{5} 1.6 \times 10^{15}$ & $1.4 \times 10^{15}$ & ${ }^{15} 1.7 \times 10^{15}$ \\
\hline & 22 & 23 & 25 & 27 & 31 & 27 & 20 & 42 & 27 \\
\hline \multicolumn{10}{|c|}{$\begin{array}{l}\text { Primary Ion: } \mathrm{O}_{2}, \\
\text { Primary Ion Energy : } 7 \mathrm{keV} \text {, } \\
\text { Pressure in Sample Chamber: } 5 \times 10^{-5} \text { Torr }\left(\mathrm{O}_{2}\right) \text {, } \\
\text { Sample: Bureau of Analyzed Sample Ltd. SS } 1 / 1 \sim 5 / 1\end{array}$} \\
\hline
\end{tabular}

\section{6. 結 言}

熱力学的解析によるIMAの定量分析法を低合金鋼に 適用した場合，実験により次のことが明らかになった。

（1）IMAの試料室を高真空にした場合 $\left(\sim 10^{-7}\right.$ Torr $)$ と酸素ガスの圧力を高くした場合 $\left(5 \times 10^{-5}\right.$ Torr $)$ のいづれにおいても同程度の誤差で定量分析がで きる。

（2）内部標準の選び方により分析誤差に相違が生じ た。また元素により分析誤差が異なるが，それは 元素固有の系統的誤差で元素濃度に侬存しない。 ここでとりあげた定量分析法において，その分析誤 差を常に検量線法と同程度に小さくすることはできな かった。しかし試料室に酸素ガスを導入するなど元素 による感度差が大きく变化するような測定条件の变更 を行なってもIMAの感度を再補正することなく定量分 析ができる。標準試料が得られない場合でも内部標準 元素が少なくとも 2 種類存在すれば定量分析が可能な ことも，この分析法の特長となっている。

\section{文献}

1 ）土井, 津山, 鹿又：日本質量分析学会第20回年会講演 要旨集, (1972) P. 11.

2 ) C. A. Andersen and J. R. Himthorne: Anal. Chem., 45, 1421 (1973).

3 ) R. Shimizu and T. Ishitani and Y. Ueshima: J. J. Appl. Phy., 13, 249 (1974).

4 ) H.W. Drawin, "Data for Plasmas in Local Thermodynamic E quilibrium", Gauthiers-Villars (1965).

5 ) L. D. Galan et al: Spectrochemica Acta, 23B, 521 (1968).

6) H. Tamura, T. Kondo, and T. Hirano: "Proc. 6th Int. Conf. X-ray Optics and Microanalysis”, University of Tokyo Press, (1972), P. 423.

7 ) 広瀬他 3 ：質量分析投稿中。

8 ）日本化学会編：実験化学講座, 丸善, 東京 (1966). 